\title{
Effect of hybrid fibers, calcium carbonate whisker and coarse sand on mechanical properties of cement-based composites
}

\author{
M. Cao, L. Li $\bowtie$, M. Khan \\ Department of Civil Engineering, Dalian University of Technology, (Dalian, China) \\ 凶lili_research@163.com
}

Received 8 February 2017

Accepted 27 September 2017

Available on line 21 May 2018

\begin{abstract}
Nowadays researchers are developing a new hybrid fiber reinforced cement-based composites (HyFRCC). The new HyFRCC can restrain micro-cracking, improves compressive and flexural performance of beams by addition of calcium carbonate $\left(\mathrm{CaCO}_{3}\right)$ whisker, polyvinyl alcohol (PVA) fiber and steel fiber. In this work, a mix optimization procedure is shown for multi-scale HyFRCC, with steel, PVA fiber and $\mathrm{CaCO}_{3}$ whisker. The new HyFRCC is explored with addition of coarse sand to further improve its mechanical properties. Additionally, the flexural performance of beam and slabs has been investigated to optimize sand gradation and fiber combination in new HyFRCC. The compressive strength, flexural strength, flexural behavior, flexural toughness, equivalent flexural strength and deflection-hardening behavior of beams and slabs are improved with optimized content of sand gradation, fibers and $\mathrm{CaCO}_{3}$ whisker. The HyFRCC slab with $1.5 \%$ steel fiber, $0.4 \%$ PVA fiber, $1 \% \mathrm{CaCO}_{3}$ whisker and optimized coarse sand showed overall best properties.
\end{abstract}

KEYWORDS: Composite; Microcracking; Calcium carbonate; Compressive strength; Flexural strength;

Citation/Citar como: Cao, M.; Li, L.; Khan, M. (2018) Effect of hybrid fibers, calcium carbonate whisker and coarse sand on mechanical properties of cement-based composites. Mater. Construcc. 68 [330], e156 https://doi.org/10.3989/ mc.2018.01717

RESUMEN: Effecto de fibras híbridas, filamentos de carbonato cálcico y arena gruesa en las propiedades mecánicas de cementos compuestos. En la actualidad se están desarrollando nuevos cementos compuestos reforzados con fibras híbridas (HyFRCC, por sus siglas en inglés). Estos nuevos cementos HyFRCC pueden impedir la microfisuración y aumentar la resistencia a compresión y flexotracción de las vigas, mediante la incorporación de filamentos de carbonato cálcico $\left(\mathrm{CaCO}_{3}\right)$, fibras de alcohol polivinílico (PVA) y fibras de acero. En este trabajo se plantea un procedimiento para optimizar la proporción de fibras (de acero y de PVA) y filamentos (de $\mathrm{CaCO}_{3}$ ) en un nuevo HyFRCC. Se investiga la influencia de la arena gruesa en sus propiedades mecánicas, además de la resistencia a flexotracción de vigas y forjados a fin de adecuar la granulometría de la arena y la combinación de fibras en el nuevo material. Un buen ajuste entre el contenido y la granulometría de la arena y la proporción de las fibras y de los filamentos de $\mathrm{CaCO}_{3}$ permite: incrementar la resistencia tanto a compresión como a flexotracción, la tenacidad a flexotracción y la resistencia a flexotracción equivalente; perfeccionar el comportamiento a flexión; y reducir la flecha de vigas y forjados endurecidos. La mezcla que mejores resultados arroja en conjunto contiene 1,5\% de fibras de acero, $0,4 \%$ de fibras de PVA, $1 \%$ de filamentos de $\mathrm{CaCO}_{3}$ y arena gruesa optimizada.

PALABRAS CLAVE: Composite; Microfisuras; Carbonato cálcico; Resistencias a compresión; Resistencias a flexión

ORCID ID: M. Cao (http://orcid.org/0000-0002-7917-4710); L. Li (http://orcid.org/0000-0003-3966-6363); M. Khan (http://orcid.org/0000-0003-2898-1827)

Copyright: (C) 2018 CSIC. This is an open-access article distributed under the terms of the Creative Commons Attribution 4.0 International (CC BY 4.0) License. 


\section{INTRODUCTION}

The cracking and failure of cement-based composites is a gradual multi-scale process under an action of load, pre-existing or new born microncracks grow and convert to meso-cracks and then macro-cracks. Eventually, the macro-cracks lead to the failure of the structural members (1-3). The various fibers with different dimensions and properties are generally added into cement-based composites to restrict the growth of cracks at different stages in the failure process; and improve its strength, toughness and ductility $(1,4-15)$. But the high cost of fibers limited the large-scale construction project for the applications of fiber reinforced cement-based composites. The amount of cement and expensive fibers are reduced in cement based composites to lower its product cost $(10,12)$. Hence, decreasing the amount of expensive fibers without sacrificing the mechanical performance of fiber reinforced cement-based composites will become beneficial.

Recently, researchers $(5,15)$ have worked on the development of a multi-scale cost-effective hybrid fiber reinforced cement-based composites (HyFRCC) incorporating micron calcium carbonate $\left(\mathrm{CaCO}_{3}\right)$ whisker to restrain the initiation and growth of micro-cracks. In comparison with HyFRCC incorporating steel and polyvinyl alcohol (PVA) fiber $(4,13,14)$; the steel fiber $(\$ 2800$ per ton) and PVA fiber ( $\$ 5950$ per ton) were partially replaced by cheaper $\mathrm{CaCO}_{3}$ whisker ( $\$ 236$ per ton) mainly to improve the mechanical performance as well as reduce the production cost. The mechanical properties and economic efficiency of the new HyFRCC are shown in Table 1. The fiber cost of HyFRCC with $1.5 \%$ steel fiber, $0.4 \%$ PVA fiber and $1 \% \mathrm{CaCO}_{3}$ whisker (by total volume fraction) is $\$ 365$ per cubic meter, while that with $2 \%$ steel fiber (by total volume fraction) is $\$ 437$ per cubic meter according to Chinese market price. The flexural toughness and number of cracks at mid span of HyRCC incorporating 1.5\% steel fiber, $0.4 \%$ PVA fiber and $1 \% \mathrm{CaCO}_{3}$ whisker are increased by $20 \%$ and $760 \%$, respectively, as compared to that of HyRCC with $2 \%$ steel fiber (5). The new HyFRCC can restrain plastic shrinkage, improves compressive and flexural performance of beams efficiently by addition of micro- $\mathrm{CaCO}_{3}$ whisker, meso- PVA fiber and macro- steel fiber $(5,15)$. The content of fine silica sand can be reduced by using coarser fine aggregate. This is another useful way to reduce the price of high performance fiber reinforced cementbased composites as well as to improve its dimensional stability (16). The coarser fine aggregate may affect the behavior of the composite, e.g., rheological property of fresh mixture, fiber dispersibility and toughness $(17,18)$. Hence, the fine aggregate particles sizes in the new HyFRCC needs to be optimized. The flexural performance of cement-based composites are influenced by specimen size and geometry (19-22). The HyFRCC is studied for various structural applications (23-25). Therefore, it is necessary to study the flexural performance of slabs for the large-scale engineering application of the new HyFRCC in thin members, e.g., bridge deck, surface repair of structure, impact and blast resistant protective panel.

\section{RESEARCH SIGNIFICANCE}

A new cost-effective multi-scale HyFRCC, with micron $\mathrm{CaCO}_{3}$ whisker has been developed to restrain micro-cracks. In comparison with

TABLE 1. Mechanical properties and economic efficiency of the new HyFRCC (5)

\begin{tabular}{|c|c|c|c|c|c|c|}
\hline Group \# & $\begin{array}{l}\text { Compressive } \\
\text { strength } \\
\text { (MPa) }\end{array}$ & $\begin{array}{l}\text { Flexural strength } \\
\text { (MPa) }\end{array}$ & $\begin{array}{c}\text { Flexural } \\
\text { toughness } \\
(\mathbf{N} \cdot \mathbf{m})\end{array}$ & $\begin{array}{c}\text { Equivalent } \\
\text { flexural strength } \\
(\mathrm{MPa})\end{array}$ & $\begin{array}{l}\text { Mid-span crack } \\
\text { number(s) }\end{array}$ & $\begin{array}{l}\text { Fiber and whisker } \\
\text { cost }\left(\$ / \mathrm{m}^{3}\right)\end{array}$ \\
\hline S2 & 105.4 & 15.6 & 17.48 & 10.9 & 1 & 437 \\
\hline $\mathrm{S} 1.75 \mathrm{P} 0.25$ & 94.6 & 16.9 & 19.16 & 12 & 2.3 & 402 \\
\hline $\mathrm{S} 1.75 \mathrm{P} 0.2 \mathrm{~W} 0.5$ & 98.6 & 18.1 & 19.82 & 12.4 & 4.5 & 401 \\
\hline $\mathrm{S} 1.5 \mathrm{P} 0.5$ & 92.3 & 18.8 & 20.01 & 12.5 & 3.7 & 366 \\
\hline $\mathrm{S} 1.5 \mathrm{P} 0.4 \mathrm{~W} 1$ & 95.1 & 20.1 & 21.01 & 13.1 & 8.6 & 365 \\
\hline $\mathrm{S} 1.25 \mathrm{P} 0.75$ & 88.7 & 18.3 & 19.15 & 11.9 & 5.4 & 331 \\
\hline $\mathrm{S} 1.25 \mathrm{P} 0.55 \mathrm{~W} 2$ & 89.3 & 19.3 & 21.41 & 13.2 & 11.6 & 329 \\
\hline S1P1 & 85.1 & 16.7 & 17.10 & 10.7 & 5.3 & 296 \\
\hline S1P0.7W3 & 87.4 & 16 & 15.92 & 9.9 & 6.6 & 292 \\
\hline $\mathrm{S} 0.75 \mathrm{P} 1.25$ & 85.5 & 14.8 & 14.27 & 8.9 & 3.8 & 261 \\
\hline $\mathrm{S} 0.75 \mathrm{P} 0.85 \mathrm{~W} 4$ & 90.7 & 13.9 & 13.06 & 8.2 & 3.2 & 256 \\
\hline
\end{tabular}

Note: Where S,P and W in group \# denotes steel fiber, PVA fiber and CaCO3 Whisker, respectively. The numeric value after S, P and W shows the percentage of fibers by total volume fraction. 
conventional HyFRCC (only incorporating steel and PVA fibers), the steel fibers and PVA fibers were partially replaced by cheaper $\mathrm{CaCO}_{3}$ whiskers mainly to control micro-cracking as well as to reduce the production cost. In this research, the influence of sand size and granular composition of the new HyFRCC are studied in order to further reduce its unit cost as well as to improve its mechanical properties. Moreover, the flexural performance of beam and slab specimens are investigated to optimize the combination of fibers and sand gradation in new HyFRCC. In addition to this, the current research tries to provide a reference in optimizing mixture for future investigations of cement-based composites containing hybrid fiber. In this study, several parameters are evaluated in the optimization of the new HyFRCC: (i) four kinds of sands with various size and graduation are considered; (ii) five different fibers combinations are used; and (iii) two types of specimens i.e. beam and slab are studied. The compressive strength, flexural strength, flexural behavior, flexural toughness, equivalent flexural strength, loaddeflection curves, deflection-hardening behavior, failure mode of slab and beam specimens and fracture morphology of cubes, beams and slabs are emphasized and discussed in detail.

\section{OPTIMIZATION PROCEDURE}

The optimization of the new HyFRCC is composed of three main steps. The first step is to choose the better combination of fibers from prior work (5) considering following parameters: i.e. flexural properties, fracture performance of beams, compressive strength, microstructures, reinforcing mechanisms, and economic efficiency of HyFRCC. As shown in Table 1, two fiber combinations shows the best performance (the fiber combinations of $\mathrm{S} 1.5 \mathrm{P} 0.4 \mathrm{~W} 1$ and $\mathrm{S} 1.25 \mathrm{P} 0.55 \mathrm{~W} 2$ ). The performance of compressive and flexural properties are considered, and $\mathrm{S} 1.5 \mathrm{P} 0.4 \mathrm{~W} 1$ is chosen for current study.
The dosage of different fiber combinations by total volume fraction is shown in Table 2 . It needs to be noted that the sand used in first step is A_43_99 and physical properties are shown in Figure1 and Table 3.

The second step is to optimize the size of sand particle and granular composition. Four different granular compositions of sand are studied; and physical properties and sieve analysis of various sands used in this study are shown in Table 3 and Figure 1, respectively. The $40 \mathrm{~mm} \times 40 \mathrm{~mm} \times$ $160 \mathrm{~mm}$ beams are used for the flexural test and also compared with the result of prior study (5). The third step is optimization of fiber combination and sand graduation in slab member. The flexural behavior of HyFRCC slab using various fiber combinations (dosage of fiber combination is shown in Table 2) and the sand graduation of A_36_87 are investigated to explore the best proportion of fibers. In addition to this, the slab specimen with sand graduation of A_40_63 and fiber proportion of $\mathrm{S} 1.5 \mathrm{P} 0.4 \mathrm{~W} 1$ is also studied to determine a ideal aggregate graduation.

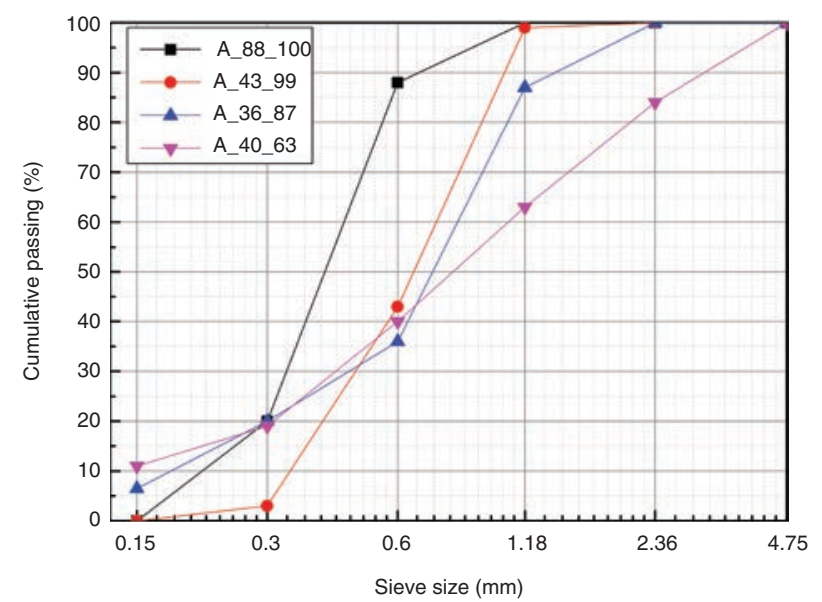

FIGURE 1. Sieve analysis of different types of sands.

TABLE 2. Dosage of different fiber combinations by total volume fraction

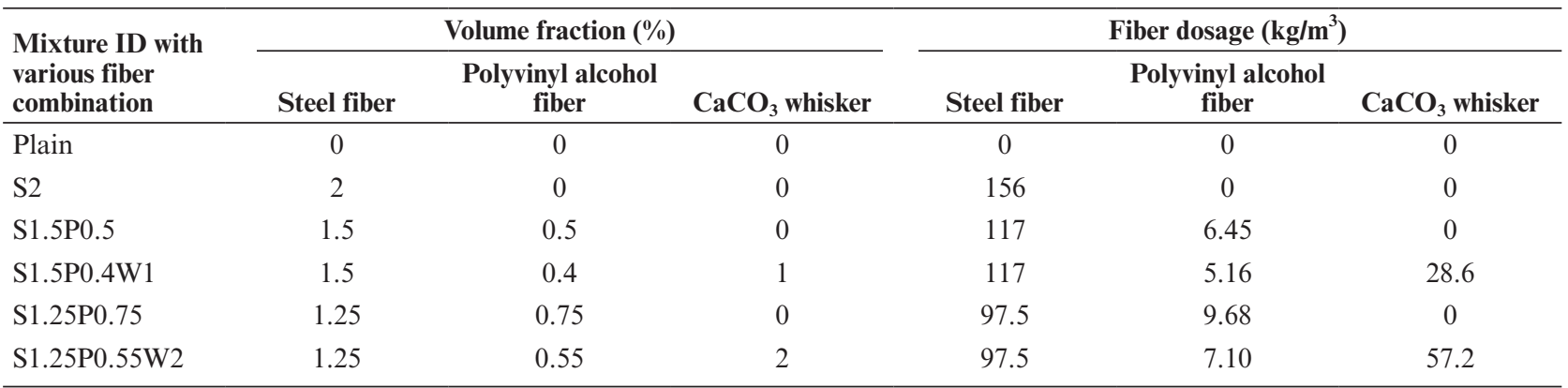

Note: S: steel fiber; P: polyvinyl alcohol fiber; and W: $\mathrm{CaCO}_{3}$ whisker. The numeric value after $\mathrm{S}, \mathrm{P}$ and $\mathrm{W}$ shows the percentage of fibers and whisker. 
TABLE 3. Physical properties of different types of sands

\begin{tabular}{lcccccc}
\hline $\begin{array}{l}\text { Mixture ID with } \\
\text { various sand } \\
\text { grading }\end{array}$ & $\begin{array}{c}\text { Density } \\
\left(\mathbf{g} / \mathbf{c m}^{\mathbf{3}}\right)\end{array}$ & Moh's hardness & $\begin{array}{c}\text { Cumulative } \\
\text { percent passing } \\
\text { of } \mathbf{0 . 6 m m} \\
\mathbf{( \% )}\end{array}$ & $\begin{array}{c}\text { Cumulative } \\
\text { percent passing } \\
\text { of 1.18mm } \\
\mathbf{( \% )}\end{array}$ & $\begin{array}{c}\text { Maximum } \\
\text { aggregate size } \\
(\mathbf{m m})\end{array}$ & $\begin{array}{c}\text { Percent retained } \\
\text { of 1.18mm sieve } \\
(\mathbf{\%})\end{array}$ \\
\hline A_88_100 & 2.65 & 7 & 88 & 100 & 1.25 & 0 \\
A_43_99* & 2.65 & 7 & 43 & 99 & 2.50 & 1 \\
A_36_87 & 2.65 & 7 & 36 & 87 & 2.50 & 13 \\
A_40_63 & 2.65 & 7 & 40 & 63 & 5.00 & 37 \\
\hline
\end{tabular}

Note: * show the sand results taken from study of Cao et al. (5).

\section{EXPERIMENTAL DETAILS}

\subsection{Materials and mixture proportions}

The mortar was made with ordinary cement (P.O 42.5R), quartz sand (properties of sand are shown in Table 2 and grading curves of the sand is given in Figure1), steel fiber (straight round cylindrical type), PVA fiber and $\mathrm{CaCO}_{3}$ whisker. The details of ingredient properties and chemical constituents are shown in Tables 4 and 5, respectively. In second step, for each aggregate graduation, six cubes of size $70.7 \mathrm{~mm}$ (length) $\times 70.7 \mathrm{~mm}($ width $) \times 70.7 \mathrm{~mm}$ (height) for compressive strength test were cast and six $40 \mathrm{~mm}$ (depth) $\times 40 \mathrm{~mm}$ (width) $\times 160 \mathrm{~mm}$ (length) prisms for flexural test were produced. In the third step, six $100 \mathrm{~mm}$ (width) $\times 400 \mathrm{~mm}$ (length) $\times 15 \mathrm{~mm}$ (depth) slabs for each mixture were used to evaluate flexural behavior. The dosage of different fiber combinations is shown in Table 2. Moreover, six $100 \mathrm{~mm} \times 400 \mathrm{~mm} \times 15 \mathrm{~mm}$ slabs with sand graduation of A_40_63 and fiber proportion of S1.5P0.4W1 were produced as a control mix.

As illustrated in Table 2, the fiber combinations are labeled so that they can be recognized from their

TABLE 4. Properties of cement, steel fiber, PVA fiber and $\mathrm{CaCO}_{3}$ whisker

\begin{tabular}{|c|c|c|c|}
\hline $\begin{array}{l}\text { Raw } \\
\text { materials }\end{array}$ & $\begin{array}{l}\text { Density } \\
\left(\mathrm{g} / \mathrm{cm}^{3}\right)\end{array}$ & Size & $\begin{array}{l}\text { Mechanical } \\
\text { property }\end{array}$ \\
\hline Cement & 3.20 & $\begin{array}{l}\text { Specific surface } \\
\text { area } \\
356 \mathrm{~m}^{2} / \mathrm{kg}\end{array}$ & - \\
\hline Steel fiber & 7.8 & $\begin{array}{l}\text { Length } 13 \mathrm{~mm} \\
\text { Diameter } 200 \mu \mathrm{m}\end{array}$ & $\begin{array}{l}\text { Tensile strength } \\
\geq 2 \mathrm{GPa} \text { Elastic } \\
\text { modulus } \\
200-210 \mathrm{GPa}\end{array}$ \\
\hline PVA fiber & 1.29 & $\begin{array}{l}\text { Length } 6 \mathrm{~mm} \\
\text { Diameter } 31 \mu \mathrm{m}\end{array}$ & $\begin{array}{l}\text { Tensile strength } \\
1.1 \mathrm{GPa} \\
\text { Elastic modulus } \\
41 \mathrm{GPa}\end{array}$ \\
\hline $\begin{array}{l}\mathrm{CaCO}_{3} \\
\text { whisker }\end{array}$ & 2.86 & $\begin{array}{l}\text { Length } 20-30 \mu \mathrm{m} \\
\text { Diameter } 0.5-2 \mu \mathrm{m}\end{array}$ & $\begin{array}{l}\text { Tensile strength } \\
3-6 \mathrm{GPa} \\
\text { Elastic modulus } \\
410-710 \mathrm{GPa}\end{array}$ \\
\hline
\end{tabular}

IDs. The word "Plain" identifies pure mortar. The letters in the mixture names denotes the fiber type i.e. $\mathrm{S}=$ steel fiber, $\mathrm{P}=\mathrm{PVA}$ fiber and $\mathrm{W}=\mathrm{CaCO}_{3}$ whisker. The number after each letter indicates the volume fraction of each fiber, e.g., the ID "S1.5P0.4W1" identifies mixture incorporating $1.5 \%$ steel fiber, $0.4 \%$ PVA fiber and $1 \% \mathrm{CaCO}_{3}$ whisker by volume fraction. The mixture with sand graduation of A_40_63 and fiber proportion of S1.5P0.4W1 is labeled as S1.5P0.4W1*. In addition to this, the mixtures in Table 3 are also labeled so that the cumulative passing percent of $0.6 \mathrm{~mm}$ sieve and $1.18 \mathrm{~mm}$ sieve are known from their IDs. The letter "A" denotes fine aggregate. The first number after letter indicates the cumulative passing percent of $0.6 \mathrm{~mm}$ sieve and the second one indicates that of $1.18 \mathrm{~mm}$ sieve, e.g., the ID "A_36_87" identifies that the cumulative passing percent of $0.6 \mathrm{~mm}$ sieve and $1.18 \mathrm{~mm}$ sieve are $36 \%$ and $87 \%$, respectively for fine aggregate.

The water-cement ratio $(\mathrm{W} / \mathrm{C}=0.3)$ and sandcement ratio $(\mathrm{S} / \mathrm{C}=0.5)$ were selected to design matrix mixture. The amount of water reducer (Polycarboxylic acid type, ASTM C494 type F, water reducing ratio $24 \%$ ) varied from $0.5 \%$ to $0.8 \%$ by weight of cement content to ensure that the various mixes maintained the similar flow and compaction. The step by step mixing procedure is shown in Figure 2. Each step shows the mixing ingredients and mixing time. Before casting, appropriate dosage of tributyl phosphate was introduced for reducing air bubbles caused by fiber and whisker. The fresh mortar was then poured into the metal mould and vibrated for 60 s for compaction. After casting, the samples were covered with plastic sheets and kept in the laboratory. All samples were de-molded after 24 hours, and then cured at $(20 \pm 2){ }^{\circ} \mathrm{C}$ with relative humidity over $90 \%$ until the testing day. The tests were performed at the 28th day after casting.

\subsection{Test methods}

The first step was to choose the better combination of fibers from prior work (5). In second step, the compressive strength was measured 
TABLE 5. Chemical constituents of cement and $\mathrm{CaCO}_{3}$ whisker by percentage of mass

\begin{tabular}{lccccccccccc}
\hline Composition & $\mathbf{C a O}$ & $\mathbf{S i O}_{2}$ & $\mathbf{A l}_{2} \mathbf{O}_{3}$ & $\mathbf{F e}_{2} \mathbf{O}_{3}$ & $\mathbf{C O}_{2}$ & $\mathbf{M g O}$ & $\mathbf{K}_{2} \mathbf{O}$ & $\mathbf{S O}_{3}$ & $\mathbf{N a}_{2} \mathbf{O}$ & $\mathbf{P}_{2} \mathbf{O}_{5}$ & $\mathbf{M n O}$ \\
\hline Cement & 61.13 & 21.45 & 5.24 & 2.89 & 2.37 & 2.08 & 0.81 & 2.50 & 0.77 & 0.07 & 0.06 \\
Whisker & 54.93 & 0.29 & 0.11 & 0.07 & 42.07 & 2.14 & - & 0.31 & - & - & - \\
\hline
\end{tabular}

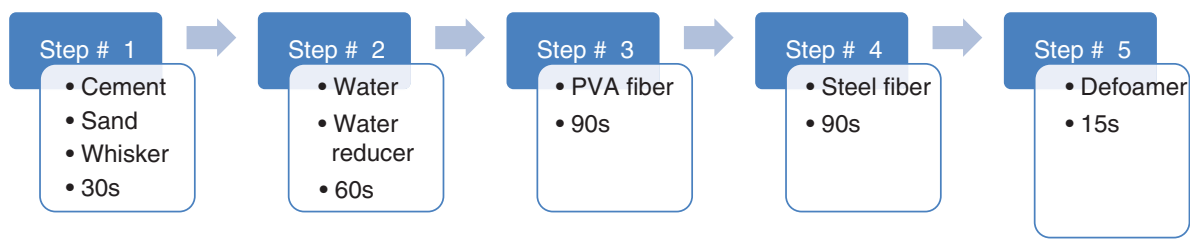

FIGURE 2. Steps for mixing procedures of fresh mortar.

using $70.7 \mathrm{~mm} \times 70.7 \mathrm{~mm} \times 70.7 \mathrm{~mm}$ specimens on a pressure machine at a crosshead speed of $0.5 \mathrm{~mm} / \mathrm{min}$ according to Chinese standard JGJ/T 70-2009. The $40 \mathrm{~mm} \times 40 \mathrm{~mm} \times 160 \mathrm{~mm}$ beams were selected for the four-point flexural behavior test in which the span length was $120 \mathrm{~mm}$. A computer-controlled hydraulic electro-servo universal tester was used at a crosshead speed of $0.05 \mathrm{~mm} / \mathrm{min}$ according to ASTM C348, ASTM C1609 and JCI-SF4. The loading method of the four-point flexural test is shown in Figure $3(L=120 \mathrm{~mm}$ and $d=40 \mathrm{~mm}$ ). The load and mid-span deflection were automatically collected by computer data acquisition system. The $100 \mathrm{~mm} \times 400 \mathrm{~mm} \times 15 \mathrm{~mm}$ slab was selected in third step for the four-point flexural behavior test in which the span length was $300 \mathrm{~mm}$. A computer-controlled hydraulic electroservo universal tester was used at a crosshead speed of $0.1 \mathrm{~mm} / \mathrm{min}$ according to ASTM C348, ASTM C1609 and JCI-SF4. The loading method of the four-point flexural test is shown in Figure 3 ( $L=300 \mathrm{~mm}$ and $d=15 \mathrm{~mm}$ ). All of the specimens are in equilibrium with the air and the mechanical

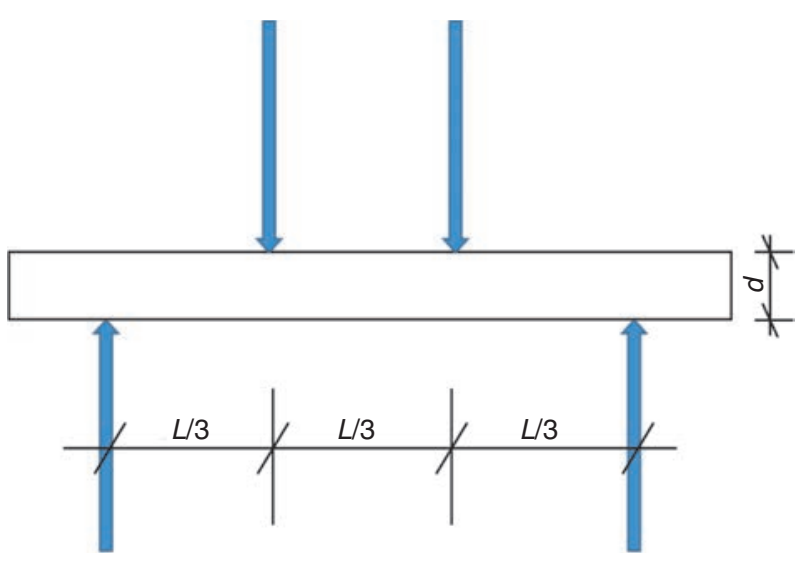

FIGURE 3. Schematic diagram of specimen under four-point flexural test. tests were carried out at $(20 \pm 3){ }^{\circ} \mathrm{C}$ having relative humidity $60-70 \%$.

The load-deflection curves were obtained from four-point flexural test. Energy absorption capacity was assessed by measuring flexural toughness $\left(T_{\mathrm{b}}\right)$, which is defined as the area under load-deflection curve upto a specific deflection. The equivalent flexural strength was determined to assess residual load-carrying ability of HyFRCCs according to JCI-SF4. The equivalent flexural strength is calculated by given formula; $\sigma_{\mathrm{b}}=\left[T_{\mathrm{b}} L\right] /\left[\delta_{\mathrm{b}} b h^{2}\right]$. Where $\sigma_{\mathrm{b}}$ is the equivalent flexural strength (MPa); $T_{\mathrm{b}}$ is flexural toughness $(\mathrm{N} \cdot \mathrm{m}) ; \delta_{\mathrm{b}}$ is a specified deflection value $(\mathrm{mm}) ; b, h, L$ are width, depth and span length, respectively. Compared to the ASTM C1018, the JCI technique can reduce human error (26). The ASTM C 1018 calculate the toughness parameters from a load-deflection curve; and their indexes are depend on the energy absorbed up to first crack (26). Unfortunately, locating the first crack point on the curve is highly subjective, it is a common belief that toughness indexes measured as per ASTM C 1018 are highly operator dependent $(1,26)$. Therefore, JCI technique was adopted to study the residual load-carrying ability of HyFRCCs because it was not depend upon first crack load.

\section{RESULTS AND ANALYSIS}

\subsection{Compressive and flexural properties}

\subsubsection{Compressive performance}

The compressive strength and relative percentage increase in compressive strength with different sand gradations are shown in Figure 4(a) and Figure 4(b), respectively. The 28-day compressive strength results varies from about 47 to $80 \mathrm{MPa}$. The mixtures incorporated with the same fiber combination (S1.5P0.4W1) have significantly increase the compressive strength with decrease in cumulative passing 
(a)

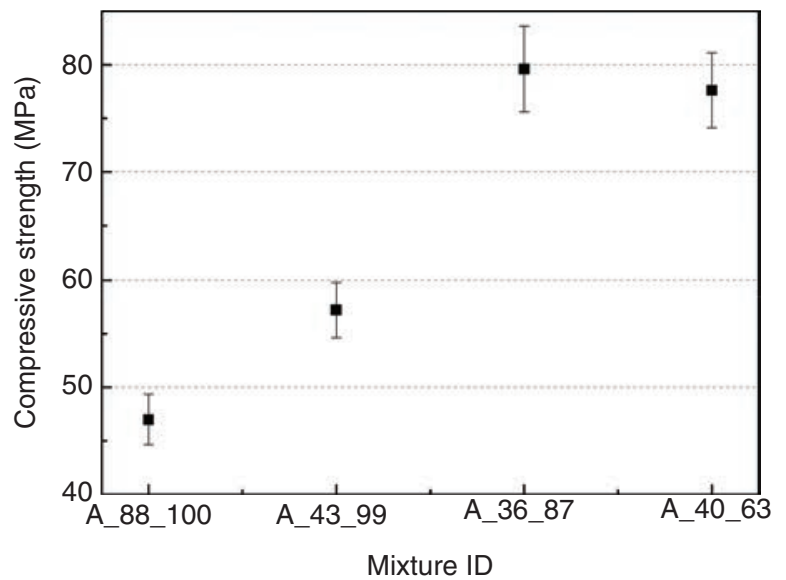

(b)

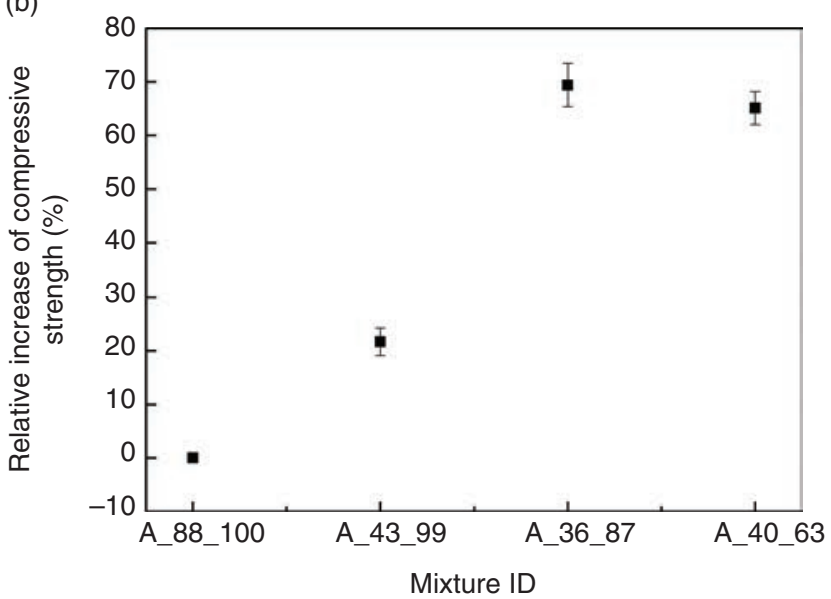

FIGURE 4. Properties of cubes with different sand gradations (a) Compressive strength and (b) Relative increase of compressive strength.

percent of $0.6 \mathrm{~mm}$ sieve and $1.18 \mathrm{~mm}$ sieve. For example, with A_43_99 and A_36_87 sand gradation the compressive strength is increased by $20 \%$ and $70 \%$, respectively, as compared to that of A_88_100. The incorporation of coarser sand in composites results in higher the compressive strength. It is obvious that under the action of load, as a crack in mortar encounters an aggregate, it propagates around the aggregate-cement paste interfaces (16). In other word, the coarser sands provides a more tortuous crack path which leads to greater energy absorption capacity and higher compressive strength.

However, as the cumulative passing percent of $1.18 \mathrm{~mm}$ sieve further decreases from A_36_87 to A_40_63, the mixture illustrates slightly lower compressive strengths. In general, too much content of coarser size fine aggregate means weak interfacial transition zone if everything else is kept the same. The weak interfacial transition zone results in a lower compressive strength of the composite (17). Moreover, coarse particle size will lead to balling of fibers and results in increased porosity of mixture, which means poor compressive performance (27). The standard deviations of A_36_87 and A_40_63 are greater than those of both A_88_100 and A_43_99 sand gradation specimens, which may caused by poor fiber dispersion.

High compressive strength of cement-based composites usually means high brittleness, hence multi-cracking behavior is necessary to meet the requirements of ductility (28). The typical fracture morphology of cubes after compressive strength test with A_40_63 and A_36_87 sand gradation are shown in Figure 5(a) and Figure 5(b), respectively. (a)

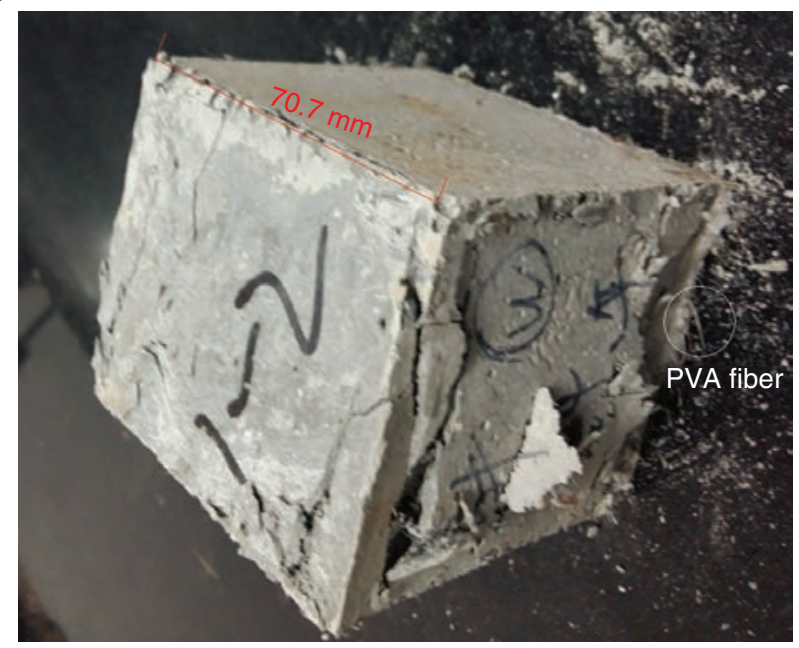

(b)

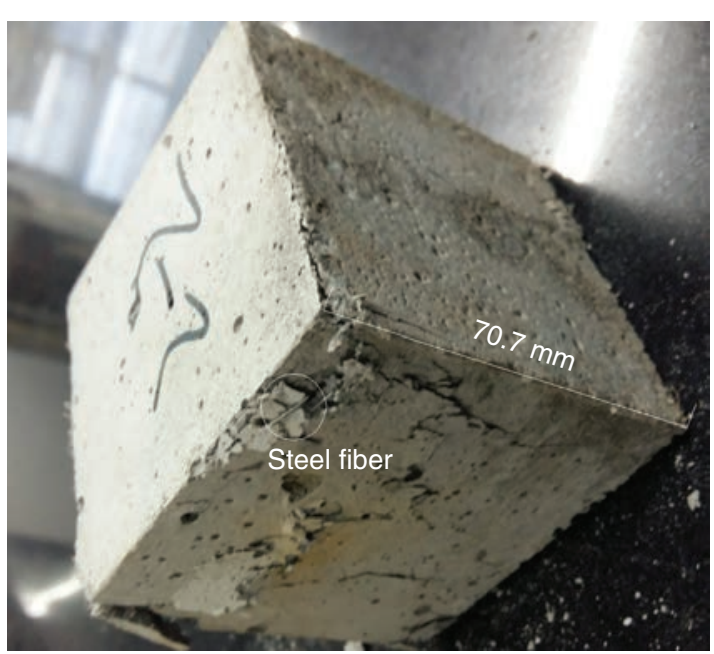

FIGURE 5. Typical fracture morphology of cubes after compressive strength test with different sand gradation (a) A_40_63 and (b) A_36_87. 
The specimens with various sand grading showed similar fracture morphology. All of the new HyFRCC samples demonstrate a ductile failure pattern and good integrity after being crushed. Small pieces of mortar and the end of some steel fiber and PVA fiber can be observed on the surface of specimens, marked by white circles in Figure 5. The hybrid effect of multi-scale fibers may delay and restrict the propagation of cracks. In addition to this, these fibers can help to hold the shear plane together under compressive load to keep the integrity of sample.

\subsubsection{Flexural strength of beams}

The flexural strength and flexural strength to compressive strength ratio of beams with different sand gradations are shown in Figure 6 (a) and Figure 6 (b), respectively. The values of flexural strength varies from 19 to $22 \mathrm{MPa}$. The results indicates that decreasing the cumulative passing percent of $0.6 \mathrm{~mm}$ sieve and $1.18 \mathrm{~mm}$ sieve from A_88_100 to A_40_63 showed decreasing and then increasing trend in flexural strength. On the other hand, A_36_87 shows the highest flexural strength along with the greatest value of compressive strength; and it is mainly due to the highest strength of matrix which is caused by coarse sands. Moreover, similar to compressive strength, further decreasing the cumulative passing percent of $1.18 \mathrm{~mm}$ sieve reduce the the flexural strength. The flexural strength is decreased more significant than compressive due to balling of fibers caused by too coarse sand (16). Similar to the compressive strength, the coarser sand also lead to the greater dispersion of the flexural strength of A_36_87 and A_40_63 than those of A_88_100 and A_43_99, respectively (see standard deviation bars in Figure 6).

(a)

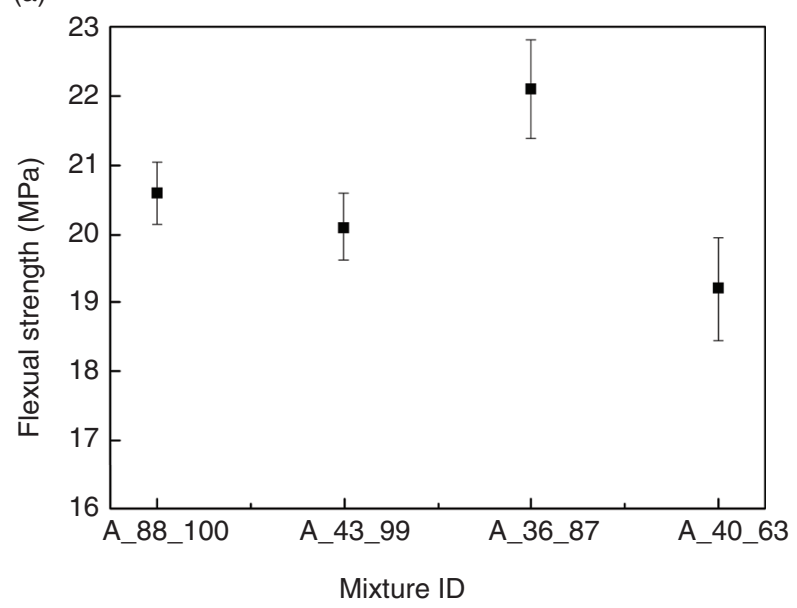

The F/C (flexural strength to compressive strength) ratio is an effective assessment indicator of toughness for cement-based composites. A high $\mathrm{F} / \mathrm{C}$ ratio generally indicates a good toughness (5). The F/C ratio is shown in Figure 6 (b), the toughness of mixture decreases significantly with the increase in sand size. More discussions about flexural toughness will be presented in the subsequent sections.

\subsubsection{Load-deflection curves of beams}

The Load-deflection curves of beams with various sand graduations are shown in Figure 7. All of the new HyFRCCs beams showed deflectionhardening behavior under the flexural load.

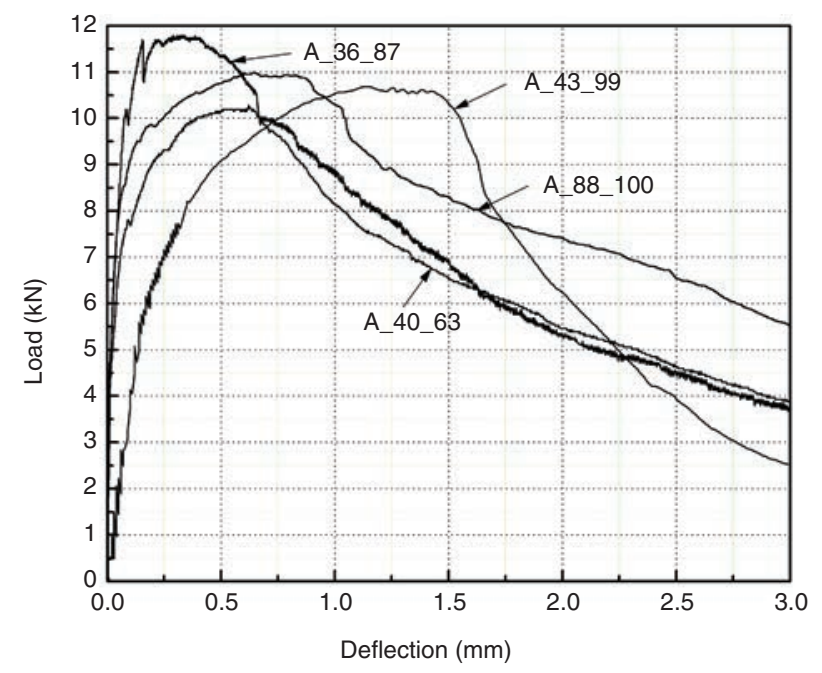

Figure 7. Load-deflection curves of beams with various sand graduations.

(b)

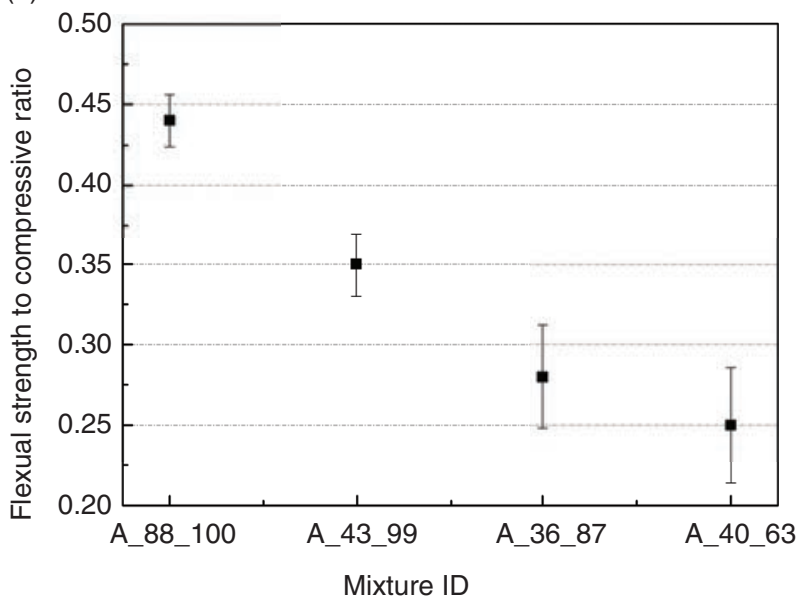

Figure 6. Properties of beams with different sand gradations (a) Flexural strength and

(b) Flexural strength to compressive strength ratio. 
The deflection-hardening behavior of HyFRCC after the first crack shows a higher load carrying capacity (29). If peak load and its respective deflection is more than that of first crack load and its respective deflection then the deflection hardening response is confirmed from this behavior (16). The mid-span deflection at their respective peak loads is the determining factor for the deflectionhardening behavior. The deflection-hardening behaviors of mixture with fine sand (A_88_100 and A_43_99) shows greater mid-span deflection at their respective peak load as compared to that of others (A_36_87 and A_40_63). On the other hand, HyFRCC with finest aggregate (A_88_100) doesn't show the improved deflection-hardening behavior; while A_43_99 shows the enhanced deflection-hardening behavior as shown in Figure 7. The strong bond between fiber and matrix interface caused by addition of finest aggregate result in poor deflection-hardening behavior (30). Therefore, the strong bond between the fiber and matrix results in fiber fracture instead of fiber pull out ultimately have less deflection hardening behavior. The A_43_99 have coarse fine aggregate with proper grading and achieved a better deflection-hardening behavior than the other mixtures.

By bridging across cracks and delaying its propagation, the hybrid fiber system improved the post-peak flexural softening behavior of the new HyFRCCs (31). Therefore, all the composites present good performance after peak load of the loaddeflection curve. Similar trend is also reported by Cao et al. (5). The A_88_100 shows flatten softening behavior after peak load. The best dispersion of fiber caused by finest aggregate may bridge the cracks most effectively (17), which finally leads to the flattest softening response of A_88_100 sand gradation.

\subsubsection{Flexural toughness and failure pattern of beams}

The flexural toughness and equivalent flexural strength of composites up to a specific deflection with different sand gradation are shown in Figure 8 (a) and Figure 8 (b), respectively. It may be noted that the span length of beam is $120 \mathrm{~mm}$. A summary of energy absorption capacity assessed by measuring flexural toughness is reported in Figure 8 (a). The area under load-deflection curve reaching a specific deflection is taken as energy absorption capacity. At small deflection $(L / 150$ and $L / 100)$, the A_36_87 and A_88_100 show greater flexural toughness than that of both A_40_63 and A_43_99.

On the other hand, for HyFRCCs with coarse sands, aggregate interlock is different bringing about high matrix toughness and work-of-fracture caused by more tortuous crack path; e.g. A_36_87 presents high flexural toughness at small deflection ( $L / 150$ and $L / 100$ ). Moreover, at higher deflection $(L / 50$ and $3 \mathrm{~mm})$, the A_88_100 shows greater flexural toughness due to the best fiber dispersion in matrix with finest aggregate. In general, the increase of coarse sands content damages the toughness at higher deflection ( $L / 50$ and $3 \mathrm{~mm}$ ) of new HyFRCCs. The coarse sands may affect the dispersion of fiber. The balling of fibers occur by coarser aggregate is due to the less coating of fibers by the cement paste; which further weak the interfacial bonding of fiber and matrix. The interfacial bonding is the determining factor for fiber to improve toughness of HyFRCCs $(17,28)$. The high strength matrix can improve the toughness of HyFRCC effectively at the initial stage (before peak load) under flexural loading, while the fiber is more effective to improve the toughness at later stage (after peak load). The results of the equivalent flexural strength are presented in Figure 8 (b). The equivalent flexural strength shows (a)

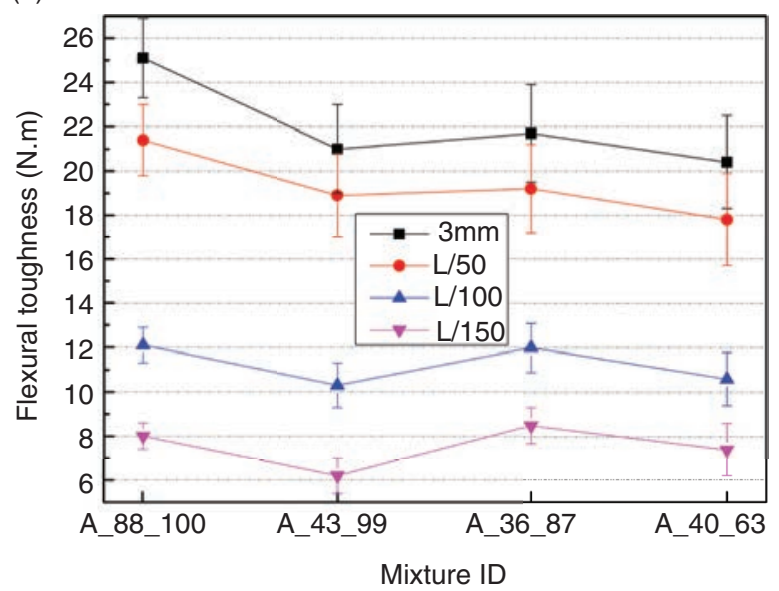

(b)

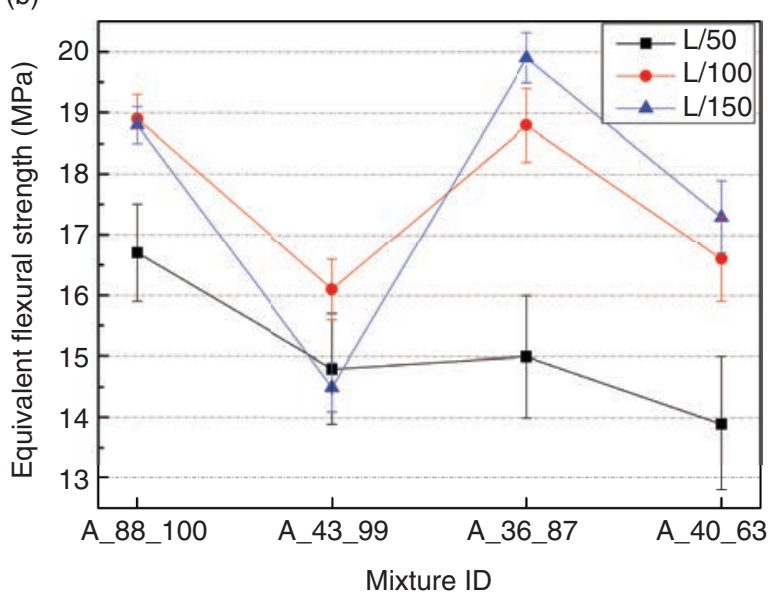

Figure 8. Properties of beam with different sand gradation (a) Flexural toughness and (b) Equivalent flexural strength of composites up to a specific deflection. 
similar pattern as reported for flexural toughness but the fluctuation is more significant. The high strength matrix can also improve the residual loadcarrying ability of HyFRCC effectively at the initial stage under flexural loading; while the fiber is more effective to improve that at the later stage than at initial stage. At small deflection level, the loadcarrying capacity depends on the production and control of micro cracks in composites due to low matrix strength, whereas the strength loss rate at coarse deflection level depends on the restriction of macro cracks by macro fibers.

The typical failure pattern of beam after flexural strength test with A_40_63, A_36_87 and A_88_100 sand gradation are shown in Figure 9 (a), Figure 9 (b) and Figure 9 (c), respectively . All of the new HyFRCCs exhibit ductile fracture under bending load and similar trend is also reported by Cao et al. (5). The multiple cracking behaviors of beams incorporating A_88_100 and A_43_99 sand gradation are better as compared to that of other two mixtures having A_36_87 and A_40_63 sand gradations. The multiple cracking behavior may be attributed to the poor dispersion of fiber; and greater matrix strength is caused by coarse sands (17). This phenomenon is in line with the various deflection-hardening response in section 5.1.3. The better deflection-hardening response generally means multiple cracking behaviors
$(16,32)$. In general, A_36_87 presents not only a improved flexural behavior but also the enhanced strength, so it is used in current research for the production of slab specimen.

\subsection{Properties of slab}

\subsubsection{Flexural strength of slabs}

The flexural strength and relative increase in flexural strength of slab are shown in Figure 10 (a) and Figure 10 (b), respectively. The relative increase in flexural strength is presented to study the reinforcing effect of fibers. Compared to plain, flexural strength of all fiber reinforced mortar increased significantly. The S1.5P0.4W1 has the highest flexural strength with increase of $370 \%$, as compared to that of plain. All the hybrid fiber systems show greater reinforcing effect than that of mono-fiber (S2). The fiber reinforced cement-based composites demonstrate a little higher value in standard deviation bar of flexural strength than that of plain. This deviation is due to the various new interfaces between fibers and matrixes (see standard deviation bars in Figure 6). On account of the smaller length and high aspect ratio, PVA fibers and $\mathrm{CaCO}_{3}$ whiskers can restrain the propagation of cracks before peak load more effectively which further improve flexural strength. (a)

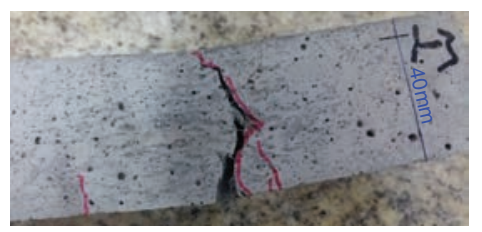

(b)

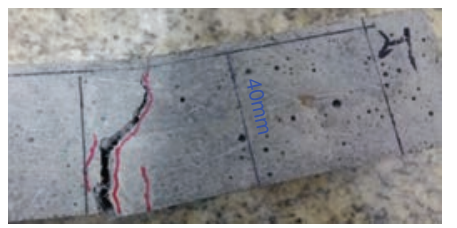

(c)

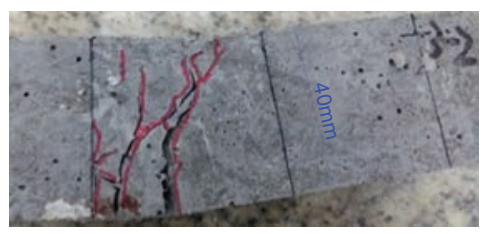

FIGURE 9. Typical failure pattern of beam after flexural strength test with different sand gradation (a) A_40_63, (b) A_36_87 and (c) A_88_100.

(a)

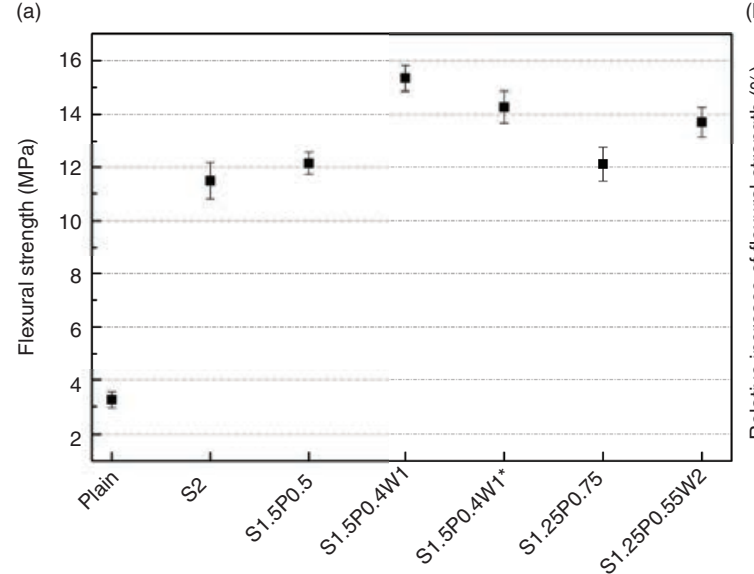

(b)

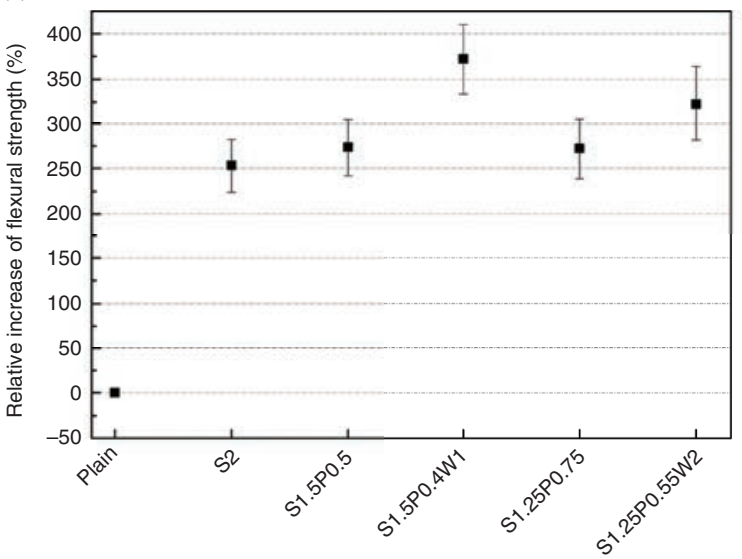

FIgure 10. Properties of slab with different sand gradations (a) Flexural strength and (b) Relative increase of flexural strength. 
However, the further increase of the amount of PVA fiber and whisker (S1.25P0.75 and S1.25P0.55W2) does not bring an expected increase in flexural strength. The poor dispersion and balling caused by higher quantity of PVA fibers and whiskers may be attributed towards reduced flexural strength. It may be noted that the flexural strength of S1.5P0.4W1* with incorporation of coarse sands slightly decrease as compared to $\mathrm{S} 1.5 \mathrm{P} 0.4 \mathrm{~W} 1$, but still greater than that of other mixtures as shown in Figure 10 (a). So, the negative effect of coarser aggregate on flexural strength of slabs is not remarkable. The new hybrid fiber system can work well along with coarser fine aggregate.

\subsubsection{Load-deflection curves of slabs}

The Load-deflection curves of slab with different fiber combination and various sizes of sand are demonstrated in Figure 11(a) and Figure 11(b), respectively. All of the HyFRCCs exhibit appreciable deflection-hardening response under bending load. Moreover, the deflection-hardening behaviors of mixtures incorporating $\mathrm{CaCO}_{3}$ whisker $(\mathrm{S} 1.5 \mathrm{P} 0.4 \mathrm{~W} 1$ and $\mathrm{S} 1.25 \mathrm{P} 0.55 \mathrm{~W} 2$ ) are better than those of without $\mathrm{CaCO}_{3}$ whisker (S1.5P0.5 and S1.25P0.75). The PVA fiber content without $\mathrm{CaCO}_{3}$ is greater than that of incorporating $\mathrm{CaCO}_{3}$ whisker. However, too much PVA fiber and $\mathrm{CaCO}_{3}$ whisker ( $\left.\mathrm{S} 1.25 \mathrm{P} 0.55 \mathrm{~W} 2\right)$ will negatively affect the deflection-hardening behavior of new HyFRCCs caused by poorer fiber dispersion. In addition to this, all HyFRCCs present improved performance after peak load in the load-deflection curve; especially, S1.5P0.4W1 presents the flatten softening behavior after peak load. This behavior is due to the multi-scale hybrid effect of the fibers and whiskers. Similar trend is also reported by Cao et al. (5). Hence, the deflection-hardening and extended

(a)

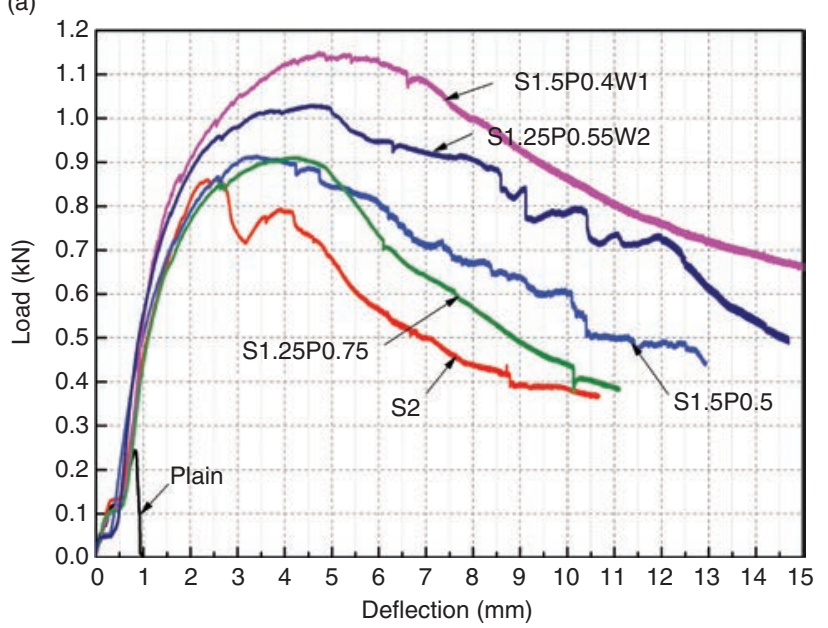

softening behavior after peak load are attributed to the addition of $\mathrm{CaCO}_{3}$ whisker.

Compared to $\mathrm{S} 1.5 \mathrm{P} 0.4 \mathrm{~W} 1$ and $\mathrm{S} 1.5 \mathrm{P} 0.5$, the curves of S1.25P0.55W2 and S1.25P0.75 present steeper slopes after peak load. Moreover, as the deflection develop is increased more than $10 \mathrm{~mm}$, the curves of S1.25P0.55W2 and S1.25P0.75 present steeper slopes than $\mathrm{S} 2$; whereas $\mathrm{S} 1.5 \mathrm{P} 0.4 \mathrm{~W} 1$ and $\mathrm{S} 1.5 \mathrm{P} 0.5$ still present a more extended behavior after peak load. This optimized steel fiber content (about $1.5 \%$ ) showed the improved load carrying capacity of new HyFRCC. As shown in Figure 11 (b), the deflection-hardening behavior of S1.5P0.4W1* incorporating coarser sands is slightly decreased as compared to that of $\mathrm{S} 1.5 \mathrm{P} 0.4 \mathrm{~W} 1$. However, it is still better than S1.5P0.5 without $\mathrm{CaCO}_{3}$ whisker due to the uniform fiber dispersion in slab member. It is obvious that the thin slab is easier to vibrate in fresh state and orientation of fibers can be uniform in composites.

\subsubsection{Flexural toughness and failure pattern of slabs}

The methods described in section 5.1.4 are adopted to evaluate energy absorption capacity, residual load-carrying ability. Figure 12(a) and Figure 12(b) shows the flexural toughness and equivalent flexural strength of composites up to specific deflection, respectively. It may be noted that the span length of slab is $300 \mathrm{~mm}$. Both flexural toughness and equivalent flexural strength of new HyFRCCs showed better performance than that of other composites. Due to the multi-scale hybrid fiber the flexural toughness and equivalent flexural strength are improved as reported by Cao et al. (5). Moreover, at small deflection $(L / 150$ and $L / 100)$, S1.25P0.55W2 shows greater flexural toughness and equivalent flexural strength than S1.5P0.4W1 because of more

FIGURE 11. Load-deflection curves of slab with various parameters (a) different fiber combination and (b) various sizes of sand. 
(a)

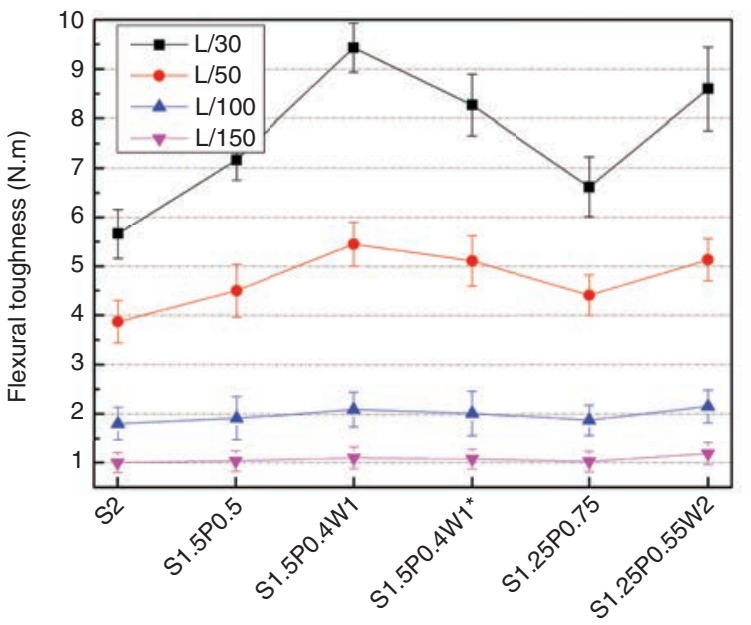

Mixture ID (b)

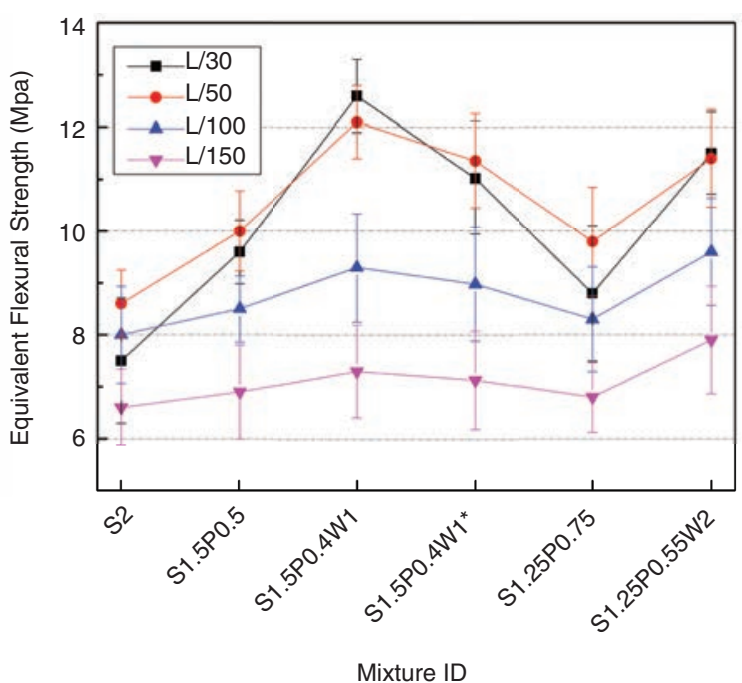

FIgURE 12. Flexural properties with different fiber combinations (a) Flexural toughness and (b) Equivalent flexural strength of composites up to specific deflection.

content of whiskers which restricts the micro cracks in composites efficiently. As discussed in section 5.1.4, the reason for improved flexural properties is that the load-carrying capacity at small deflection depends on the propagation of micro-cracks in composites. However, at higher deflection ( $L / 50$ and $L / 30) \mathrm{S} 1.5 \mathrm{P} 0.4 \mathrm{~W} 1$ presents the enhanced flexural toughness and equivalent flexural strength due to the higher amount of steel fibers. This phenomenon is mainly due to addition of multi-scale hybrid fiber and whisker in the composites. The whisker always plays an effective role to resist micro-cracking, PVA fiber controls the meso-crack and steel fiber restrain the macro-cracks $(5,28)$. The higher amount of whiskers and PVA fibers are beneficial to energy absorption capacity and residual load-carrying ability at small deflection, whereas higher quantity of steel fiber may results in improved energy absorption capacity and residual load-carrying ability at higher deflection.

The flexural toughness and equivalent flexural strength of $\mathrm{S} 1.5 \mathrm{P} 0.4 \mathrm{~W} 1$ * with coarser sands are slightly decreased as compared to those of $\mathrm{S} 1.5 \mathrm{P} 0.4 \mathrm{~W} 1$; but it is similar to $\mathrm{S} 1.25 \mathrm{P} 0.55 \mathrm{~W} 2$ and still better than $\mathrm{S} 1.5 \mathrm{P} 0.5$ without $\mathrm{CaCO}_{3}$ whisker. Compared to finest aggregate, the negative effect of coarse fine aggregate on flexural toughness and equivalent flexural strength of slabs is not remarkable. The new hybrid fiber system can work well along with coarse aggregate.

The typical failure pattern of slab after flexural testing with $\mathrm{S} 2, \mathrm{~S} 1.5 \mathrm{P} 0.5, \mathrm{~S} 1.5 \mathrm{P} 0.4 \mathrm{~W} 1$ and $\mathrm{S} 1.5 \mathrm{P} 0.4 \mathrm{~W} 1^{*}$ fiber combinations are shown in Figure 13(a), Figure 13(b), Figure 13(c) and Figure 13(d), respectively. Compared to S2, all of the HyFRCCs exhibit multiple cracking failure (a)

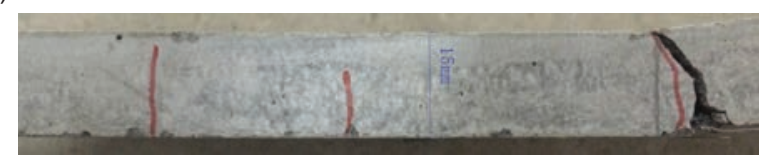

(b)

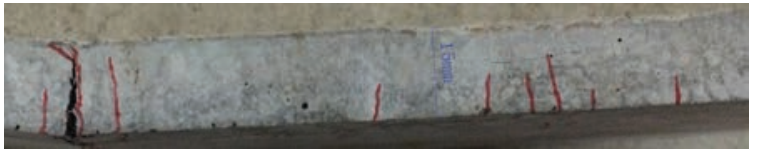

(c)

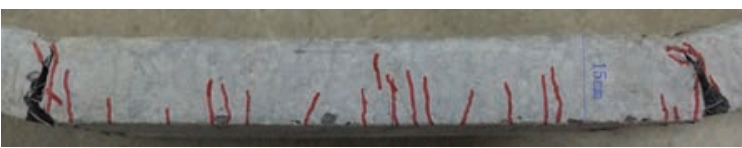

(d)

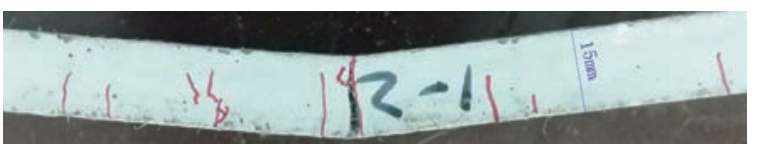

FIGURE 13. Typical failure pattern of slab after flexural testing with different fiber combinations (a) S2 (b) S1.5P0.5 (c) $\mathrm{S} 1.5 \mathrm{P} 0.4 \mathrm{~W} 1$ (d) S1.5P0.4W1*

pattern under bending load. The multiple-cracking behavior of $\mathrm{S} 1.5 \mathrm{P} 0.4 \mathrm{~W} 1$ is better than that of others. The deflection-hardening behavior of $\mathrm{S} 1.5 \mathrm{P} 0.4 \mathrm{~W} 1$ is also better as discussed earlier. However, as the amount of coarse sands increase, the S1.5P0.4W1* results in poor multiple cracking performance. The is due to poor dispersion of fiber and greater matrix strength caused by coarser sands (17). The various deflection-hardening response also verifies the multi cracking behavior. In other words, coarser aggregate reduce the multiple cracking of the new HyFRCCs. 


\section{DISCUSSION}

In general, the influence of coarse sand on the flexural behavior of HyFRCC slabs is not as severe as that on beams. The new hybrid fiber system can work well along with coarser aggregate because the compaction of slab is easier and the dispersion of fibers in slab are uniform and parallel to the span length as compared to that of beam. Similar trend is also reported by Yoo et al. (21). The uniform fiber distribution in the slab results in improved flexural properties; and the reduction in flexural properties is due to addition of coarse sand. Therefore, the solution for reduced flexural properties due to addition of coarse sand may be the uniform fiber orientation which results in improved flexural properties. The new HyFRCC beam with A_36_87 sand gradation showed better flexural strength. The flexural strength and toughness of cement-based composites showed overall best results for new HyFRCC slab incorporating coarser sand. Therefore, the optimized combination of fibers and whisker for slab is $1.5 \%$ steel fiber, $0.4 \%$ PVA fiber and $1 \% \mathrm{CaCo}_{3}$ whisker with A_36_87 sand gradation. Hence, the coarse sands with new HyFRCC can be used to produce HyFRCC slab, which have both improved strength and flexural behavior. The enhanced properties of new HyFRCC favoring its utility for the applications of bridge decks, surface repair of structures, impact and blast resistant protective panels.

\section{CONCLUSIONS}

In this research, a multi-scale hybrid fiber cementbased composites (HyFRCC) is investigated. The cheaper micron calcium carbonate $\left(\mathrm{CaCO}_{3}\right)$ whiskers are incorporated to restrain the initiation and growth of micro-cracks. The steel fiber and PVA fiber are added to control the meso-cracks and macro-cracks, respectively. A prior work has demonstrated the effectiveness of the multi-scale hybrid fiber system to improve the mechanical behavior of beam specimens and reduce the cost of the product of fiber reinforced cement-based composites (5). In this study, the new HyFRCC has been extended to the matrix with coarse sands to further improves its mechanical properties. In addition to this, the flexural performance of slabs has been investigated to optimize fiber combination and sand gradation of the new HyFRCC. The following conclusions can be drawn:

- The addition of A_36_87 coarse sands gradation improves the strength of the new HyFRCC beams effectively, whereas it slightly reduce the deflection hardening and multiple cracking performances of beams.

- The new HyFRCC slabs using coarser sand gradation of A_36_87 also brings remarkable improvement to both flexural strength and flexural toughness of cement-based composites, without sacrificing the deflection hardening and multiple cracking performances.

- The HyFRCC slabs with incorporation of $1.5 \%$ steel fiber, $0.4 \%$ PVA fiber, $1 \% \mathrm{CaCO}_{3}$ whisker (by total volume fraction) and coarse sands showed overall best properties.

- In general, the effect of coarse sands on the flexural behavior of HyFRCC slabs is not as severe as that on the beams. The new hybrid fiber system can perform well along with coarse sand.

Therefore, based on above results, the new HyFRCC can be used for structural applications with optimized content of fibers, whisker and coarser sand. The improved properties of new HyFRCC favoring its utility for the applications of bridge decks, surface repair of structures, impact and blast resistant protective panels. The coarse sands can be used to produce new HyFRCC slab having enhanced compressive and flexural properties.

\section{ACKNOWLEDGEMENTS}

The authors would like to acknowledge the support of the Natural Science Foundation of China under Grant No. 51478082 and No.51678111. The careful review and constructive suggestions by the anonymous reviewers are gratefully acknowledged.

\section{REFERENCES}

1. Banthia, N.; Soleimani, S.M. (2005) Flexural response of hybrid fiber-reinforced cementitious composites. $A C I$ Mater. J. 102[6], 382-389. https://doi.org/10.14359/14800

2. Nguyen, V. P.; Stroeven, M.; Sluys, L. J. (2012) Multiscale failure modeling of concrete: micromechanical modeling, discontinuous homogenization and parallel computations. Comp. Meth. Appl. Mech. Eng.201, 139-156. https:// doi.org/10.1016/j.cma.2011.09.014.

3. Bentz, D. P. (2000) Influence of silica fume on diffusivity in cement-based materials: II. Multi-scale modeling of concrete diffusivity. Cem. Concr. Res. 30[7], 1121-1129. https:// doi.org/10.1016/S0008-8846(00)00263-5.

4. Kang, S. T.; Choi, J. I.; Koh, K. T.; Lee, K. S. Lee, B. Y. (2016) Hybrid effects of steel fiber and microfiber on the tensile behavior of ultra-high performance concrete. Comp. Struct. 145, 37-42. https://doi.org/10.1016/j. compstruct.2016.02.075.

5. Cao, M.; Zhang, C.; Li, Y.; Wei, J. (2014) Using Calcium Carbonate Whisker in Hybrid Fiber-Reinforced Cementitious Composites. ASCE J. Mater. Civ. Eng. 27[4], 04014139. https://doi.org/10.1061/(ASCE)MT.1943-5533.0001041.

6. Kwon, S.; Nishiwaki, T.; Kikuta, T.; Mihashi, H. (2014) Development of Ultra-High-Performance Hybrid FiberReinforced Cement-Based Composites. ACI Mater. J. 111[3]. https:// 10.14359/51686890.

7. Ali, M. (2016). Use of coconut fibre reinforced concrete and coconut-fibre ropes for seismic-resistant construction. Mater. Construcc. 66 [321], e073. http://dx.doi.org/10.3989/ mc.2016.01015.

8. Khan, M.; Ali, M. (2016). Use of glass and nylon fibers in concrete for controlling early age micro cracking in bridge decks. Constr. Build. Mater. 125, 800-808. https://doi. org/10.1016/j.conbuildmat.2016.08.111. 
9. Ahmed, S. F. U.; Mihashi, H. (2011) Strain hardening behavior of lightweight hybrid polyvinyl alcohol (PVA) fiber reinforced cement composites. Mater. struct. 44[6], 1179-1191. https://doi.org/10.1617/s11527-010-9691-8.

10. Kim, D. J.; Park, S. H.; Ryu, G. S.; Koh, K. T. (2011) Comparative flexural behavior of hybrid ultra high performance fiber reinforced concrete with different macro fibers. Constr. Build. Mater. 25[11], 4144 4155. https://doi. org/10.1016/j.conbuildmat.2011.04.051.

11. Parant, E.; Rossi, P.; Boulay, C. (2007) Fatigue behavior of a multi-scale cement composite. Cem. Concr. Res. 37[2], 264-269. https://doi.org/10.1016/j.cemconres.2006.04.006.

12. Yoo, D. Y.; Banthia, N. (2016) Mechanical properties of ultra-high-performance fiber-reinforced concrete: A review. Cem. Concr. Comp. 73, 267-280. https://doi.org/10.1016/j. cemconcomp. 2016.08.001

13. Soe, K. T.; Zhang, Y. X.; Zhang, L. C. (2013) Material properties of a new hybrid fibre-reinforced engineered cementitious composite. Constr. Build. Mater. 43, 399-407. https://doi.org/10.1016/j.conbuildmat.2013.02.021.

14. Blunt, J. D.; Ostertag, C. P. (2009) Deflection hardening and workability of hybrid fiber composites. ACI Mater. J. 106[3], 265-272. https://doi.org/10.14359/56551

15. Cao, M.; Zhang, C.; Lv, H. (2014) Mechanical response and shrinkage performance of cementitious composites with a new fiber hybridization. Constr. Build. Mater. 57, 45-52. https://doi.org/10.1016/j.conbuildmat.2014.01.088.

16. Banyhussan, Q. S.; Yıldırım, G.; Bayraktar, E.; Demirhan, S.; Sahmaran, M. (2016) Deflection-hardening hybrid fiber reinforced concrete: The effect of aggregate content. Constr. Build. Mater. 125, 41-52. https://doi.org/10.1016/j. conbuildmat.2016.08.020.

17. Sahmaran, M · Lachemi, M. Hossain, K. M · Ranade, R.; $\mathrm{Li}, \mathrm{V}$. C. (2009) Influence of aggregate type and size on ductility and mechanical properties of engineered cementitious composites. ACI Mater. J. 106[3], 308-316. https:// doi.org/10.14359/56556

18. Lawler, J. S.; Zampini, D.; Shah, S. P. (2005) Microfiber and macrofiber hybrid fiber-reinforced concrete. ASCE J. Mater. Civ. Eng. 17[5], 595-604. https://doi.org/10.1061/ (ASCE)0899-1561(2005)17:5(595)

19. Şanal, I.; Özyurt, N.; Hosseini, A. (2016) Characterization of hardened state behavior of self compacting fiber-reinforced cementitious composites (SC-FRCC's) with different beam sizes and fiber types. Comp. Part B: Eng. 105, 30-45. https://doi.org/10.1016/j.compositesb.2016.06.075.

20. Wille, K.; Parra-Montesinos, G. J. (2012) Effect of Beam Size, Casting Method, and Support Conditions on Flexural Behavior of Ultra-High-Performance Fiber-Reinforced Concrete. ACI Mater. J. 109[3], 379-388. https://doi.org/ $10.14359 / 51683829$
21. Yoo, D. Y.; Banthia, N.; Kang, S. T.; Yoon, Y. S. (2016) Size effect in ultra-high-performance concrete beams. Eng. Fract. Mech. 157, 86-106. https://doi.org/10.1016/j. engfracmech.2016.02.009.

22. Nguyen, D. L.; Kim, D. J.; Ryu, G. S.; Koh, K. T. (2013) Size effect on flexural behavior of ultra-high-performance hybrid fiber-reinforced concrete. Comp. Part B: Eng. 45[1], 1104-1116. https://doi.org/10.1016/j.compositesb.2012. 07.012 .

23. Lepech, M. D.; Li, V. C. (2009) Application of ECC for bridge deck link slabs. Mater. struct. 42[9], 1185. https://doi. org/10.1617/s11527-009-9544-5.

24. Kunieda, M.; Rokugo, K. (2006) Recent progress on HPFRCC in Japan. J. Adv. Concr. Technol. 4[1], 19-33. http://doi.org/10.3151/jact.4.19.

25. Maalej, M.; Quek, S. T; Ahmed, S. F. U.; Zhang, J.; Lin, V. W. J.; Leong, K. S. (2012) Review of potential structural applications of hybrid fiber Engineered Cementitious Composites. Constr. Build. Mater. 36, 216-227. https://doi. org/10.1016/j.conbuildmat.2012.04.010.

26. Banthia, N.; Majdzadeh, F.; Wu, J.; Bindiganavile, V. (2014) Fiber synergy in Hybrid Fiber Reinforced Concrete (HyFRC) in flexure and direct shear. Cem. Concr. Comp. 48, 91-97. https://doi.org/10.1016/j.cemconcomp.2013. 10.018 .

27. Sahmaran, M. S.; Yücel, H. E.; Demirhan, S.; C Li, V. (2012) Combined Effect of Aggregate and Mineral Admixtures on Tensile Ductility of Engineered Cementitious Composites. ACI Mater. J. 109[6], 627-637. https://doi.org/10.14359/ 51684160

28. Cao, M.; Zhang, C.; Wei, J. (2013) Microscopic reinforcement for cement based composite materials. Constr. Build. Mater. 40, 14-25. https://doi.org/10.1016/j.conbuildmat. 2012.10.012.

29. Shaikh, F. U. A. (2013) Deflection hardening behaviour of short fibre reinforced fly ash based geopolymer composites. Mater. Design 50, 674-682. https://doi.org/10.1016/j. matdes.2013.03.063.

30. Li, V. C. (2012) Tailoring ECC for special attributes: A review. Int. J. Concr. Struct. Mater. 6[3], 135-144. https://doi. org/10.1007/s40069-012-0018-8.

31. Yao, W.; Li, J.; Wu, K. (2003) Mechanical properties of hybrid fiber-reinforced concrete at low fiber volume fraction. Cem. Concr. Res. 33[1], 27-30. https://doi.org/10.1016/ S0008-8846(02)00913-4.

32. Khan, M. I.; Fares, G.; Mourad, S.; Abbass, W. (2016) Optimized Fresh and Hardened Properties of StrainHardening Cementitious Composites: Effect of Sand Size and Workability. ASCE J. Mater. Civ. Eng. 28[12], 04016152. https://doi.org/10.1061/(ASCE)MT.1943-5533. 0001665 . 